\title{
IoT Prototype Development of Automatic Fish Feeder and Water Replacement
}

\author{
Devi Ratnasari ",a,1, Rodhiyah Mardhiyyah ${ }^{\text {b,2, }}$, Arif Pramudwiatmoko ${ }^{c, 3}$ \\ ${ }^{a, b}$ University of Technology Yogyakarta, Yogyakarta, Indonesia \\ a,b Tokyo Institute of Technology, Tokyo, Japan \\ ${ }^{1}$ deviratnasari@staff.uty.ac.id *; ${ }^{2}$ rodhiyah@staff.uty.ac.id, pramudwiatmoko.a.aa@m.titech.ac.jp
}

\begin{abstract}
In raising the freshwater fish in the aquarium, we need to pay attention to the fish's health by noticing the feeding time and the aquarium cleanness. The busy fish owners sometimes do not have time to clean the aquarium and replace the water. The food is even not given regularly. The system which can be developed to help the fish owners in handling the problems in raising the fish is the scheduled automatic feeding monitoring system and automatic water changer when the water has turned turbid. The system is developed by using the NodeMCU ESP8266 as the controlling center and at the same time, it helps the system to connect to the internet. The system is equipped with a website page to help the fish owner in monitoring the aquarium condition from the distance.
\end{abstract}

Keywords: Automatic fish feeder, Internet of Things, NodeMCU, Smart aquarium

\section{INTRODUCTION}

Nowadays, many people are raising freshwater decorative fish not only as a hobby but also as a job. Many people use the aquarium to raise the freshwater decorative fish. An aquarium is defined as a glass box that usually has water plants or other decorations in it as a place to raise the decorative fish [1]. In Indonesia, decorative fish has become one of the dominant living fish commodities in the fish trading traffic. Even according to the actual data from the BPS in 2017, the decorative fish export value reached USD 27.61 million [2]. This phenomenon makes the decorative fish an attractive business potential instead of only as a hobby. Several factors which should be noticed in maintaining the fish's health, growth and development of fish raising and breeding are the food, the light condition as well as the water quality. The feeding should be done regularly at a certain time and with a certain volume. Besides, the water condition in the aquarium should be noticed as well. The water should be remaining clear to keep the oxygen available for the fish [3].

\section{RESEARCH METHOD}

The research object is the monitoring system and aquarium tools prototype using NodeMCU ESP8266. NodeMCU functions as a microcontroller or system controlling center which is at the same time functions as a Wi-Fi module to enable the developed system to be connected to the internet and the monitoring process can be implemented through the website page. The research focus is the system design which enables the system to be multifunctional, such as to monitor the food volume, to be the periodical automatic feeder, to monitor the water turbidity level, and to automatically replace the water when it is needed. The monitoring system will use the website page.

This research adopts the waterfall model developing method which has the up bottom developing model. It is called the waterfall model because the steps should be taken in order. The research will be implemented in several steps as shown in the scheme of Figure 1.

This research also avoids combining SI and CGS units, such as the current in amperes and the magnetic field in an oersted. Combining SI and CGS often leads to confusion because equations do not balance dimensionally. If you must use mixed units, clearly state the units for each quantity that you use in an equation.

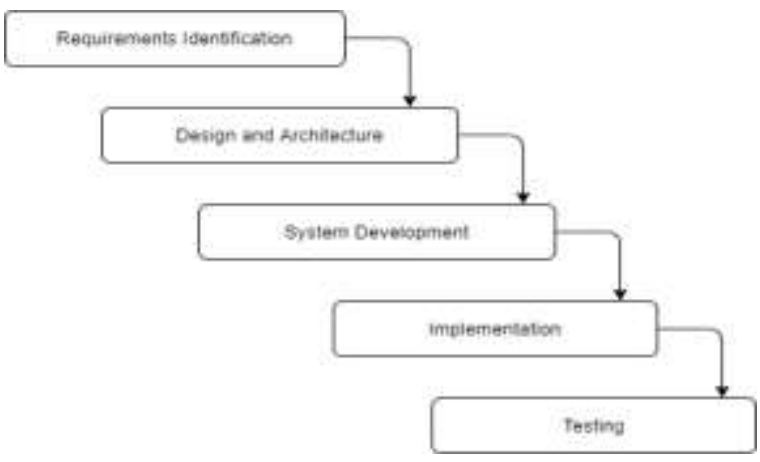

Figure 1. Waterfall Model

The research starts from analyzing the problems. This step is done by reviewing some literature with a similar research domain [6]. It aims to obtain the general review of the problems as well as the solution to find the conclusion on the system concept and development planning.

The system requirements identification step is the step of identifying the functional and non-functional needs of the system. The identification is applied to determine the required hardware and software in developing the system entirely [7]. In this stage, we also select the sensor module to measure the distance, the sensor module to measure the water turbidity level, the microcontroller, the Wi-Fi module, and other tools. 
The architecture design step is the step of describing how the developed system will work based on the identified system requirement. The activities which are done in this step are prototype architecture design, input and output design, and also problemsolving procedure design in the system by using the flowchart. Architecture design consists of the software and hardware planning process.

The system development step is implemented by building the hardware installation (prototyping) based on the system architecture design and doing the system coding which translates the software design into the program coding. Coding is implemented by using the $\mathrm{C}$ Arduino language, then to create the database we apply MySQL and website interface pages by using PHP and CSS.

After the prototype and monitoring system building process has finished, then the next step is to check the system performance and quality. The product implementation and the product test should be implemented for the program and the electronic devices. It makes sure that the system can work without bugs and errors and it works as the expected business process. The electronic devices test is in the form of a sensor instruction system to measure the water turbidity level, sensor system to measure the food volume and system response toward any condition based on the data taken through the sensor system as well as to observe the entire monitoring system.

\section{SYSTEM DEVELOPMENT}

\section{A. System Planning}

The developed aquarium generally has the functional system as follow:

1. The system can automatically feed the fish in a certain periodical time.

2. The system can measure the water turbidity level.

3. The system makes use of the microcontroller and the Wi-Fi module which is connected to the internet.

4. The system can monitor the aquarium in a real-time condition and can save the data from the acquisition result into the database and enable the users to check it from the website.

5. The system can measure the food volume in the food container and can inform the users when the food volume has reached the minimum limitation.

The data manager or the main controller of the tool is the NodeMCU ESP 8266. The microcontroller has a Wi-Fi module that can directly connect to the internet so that the monitoring process can be done from the website. The microcontroller also functions as the input data receiver and managers such as the LDR sensor and ultrasonic sensor, while the water tab, water pump, and servo function as the actuator to run the tools. The block diagram is shown in Figure 2.

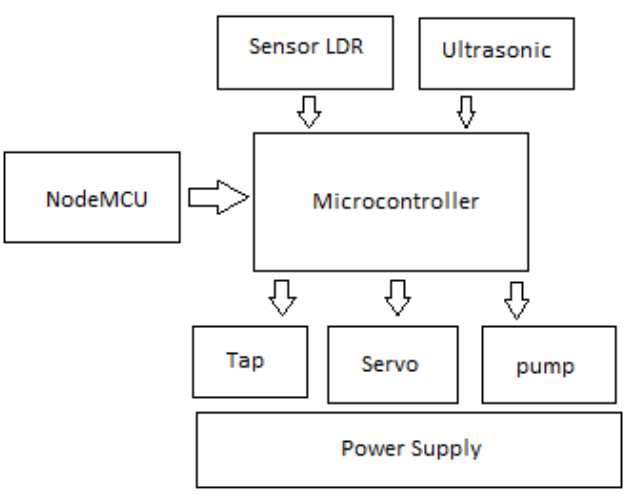

Figure 2. Block diagram

The tools procedure is started by activating the microcontroller installation and then the LDR sensor will identify the water turbidity level in the aquarium and perform it on the website page. The flowchart is shown in Figure 3.

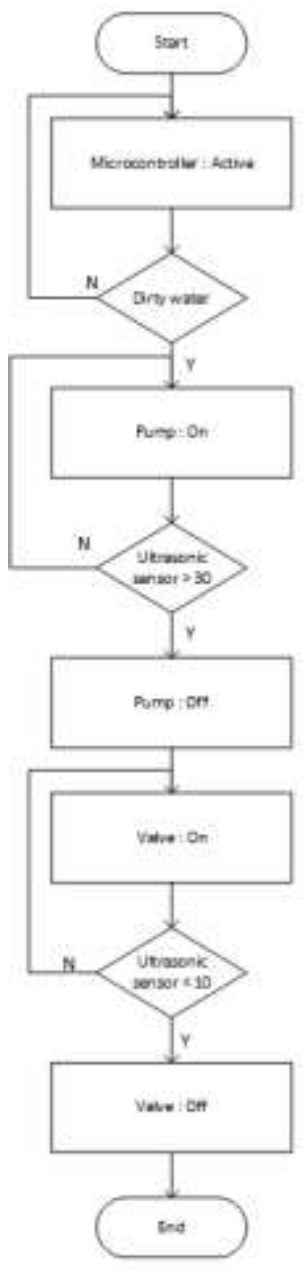

Figure 3. Flowchart

Several electronic components are installed and connected. They are NodeMCU ESP8266 as the microcontroller, LDR (Light Dependent Resistor) Sensor, ultrasonic sensor, servo, relay, and RTC (Real Time Clock). The result data of the sensor system and 
the time in the website are processed by the microcontroller as an input which is later this data becomes the stimulus to run the aquarium prototype function. The data is then saved in the database.

\section{B. Implementation}

The building of an automatic fish feeder aquarium uses NodeMCU ESP8266 as the microcontroller which functions as the data receiver and data manager. The automatic aquarium system installation is installed and set in a box which is located on the aquarium. In the box, we can find the ultrasonic sensor, NodeMCU, and some other components as it is shown in Figure 4.

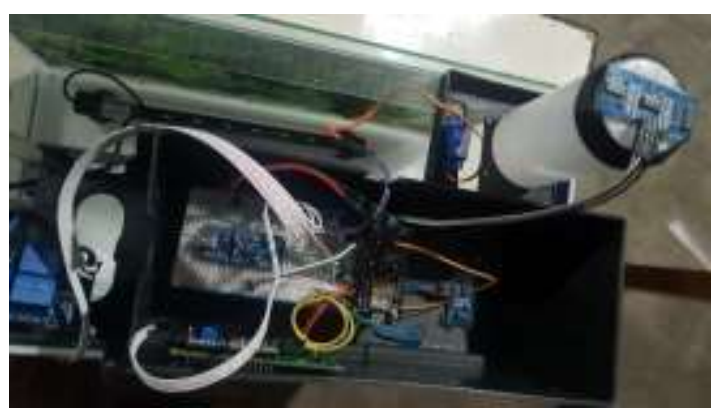

Figure 4. Installation box

The aquarium is equipped with the detection of the food volume in the food container by using an ultrasonic sensor. The food container can be automatically opened under the fish feeding schedule. The result of food volume detection then will be performed on the LCD screen. The design of the food container is shown in Figure 5.

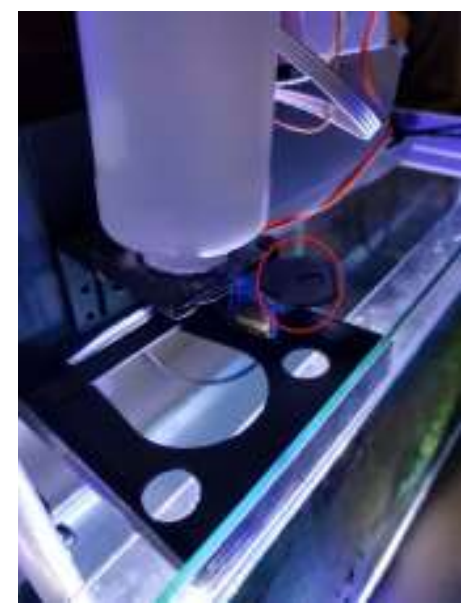

Figure 5. Fish food container.

The LDR sensor is applied to detect the water turbidity level in the aquarium. The LDR sensor is installed on the outer side of the aquarium as shown in Figure 6.

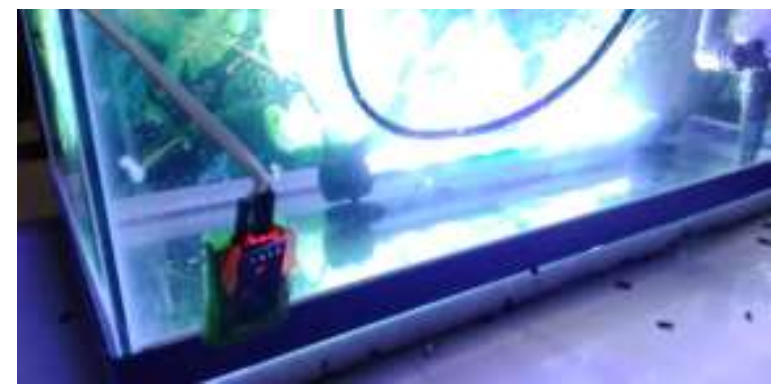

Figure 6. LDR sensor installation

The automatic aquarium can automatically dispose of the water when the high water turbidity level is identified by pumping it out through the pipes. The water disposal pipes installation is shown in Figure 7.

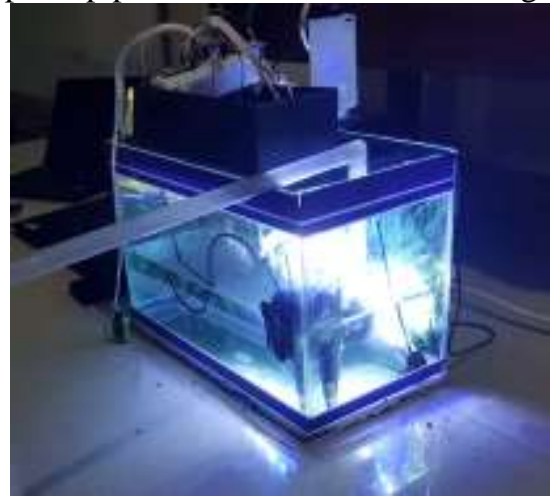

Figure 7. Water disposal pipes installation

The automatic fish feeder aquarium is also able to replace the water when the aquarium has been empty. The water filling installation is as it is shown in Figure 8 where the water container is located higher than the aquarium to enable the water to flow down to the aquarium smoothly. While the water disposal is connected by using the pipes so that the turbid water can be disposed to the water disposal container.

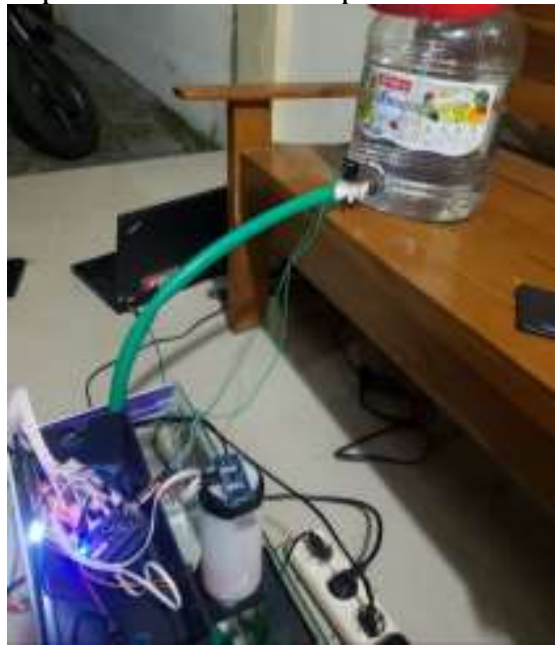

Figure 8. Water tab installation

The automatic fish feeder aquarium system is equipped with a website page in which the website functions to manage the feeding schedule. Besides, the 
website page also functions to monitor the aquarium condition anywhere and anytime.

\section{FINDING AND DISCUSSION}

The smart aquarium is developed by using NodeMCU as the microcontroller or as the processing center and at the same time, it works as a Wi-Fi module to connect the tools to the internet. The smart aquarium uses the ultrasonic sensor which has a function as the fish food availability detection and the water level detection in the aquarium. It uses the LDR sensor to detect the water turbidity level as well.

Besides, the actuator which is used in the smart aquarium is the servo motor which is set on the lid of the food container. The servo has a function to open and close the food container at the scheduled time. The smart aquarium will use the water pump to dispose of the aquarium water when the limited water turbidity level is detected by the LDR system. The water pump will stop working after the water is disposed of and it is less than $10 \mathrm{~cm}$ in height, the water tab then will be opened to replace the aquarium water until it reaches $30 \mathrm{~cm}$ in height.

The fish food availability is detected by using the ultrasonic sensor by measuring the distance of the sensor tools with the food surface so that the fish food volume in the food container can be detected.

The activities in the aquarium can be monitored either directly or indirectly from the distance. The direct aquarium monitoring can be done from the information which is performed in the LCD in which the LCD has the function to give information about fish food volume, water turbidity level as well as water height level. The example of aquarium status information is shown in Figure 9.

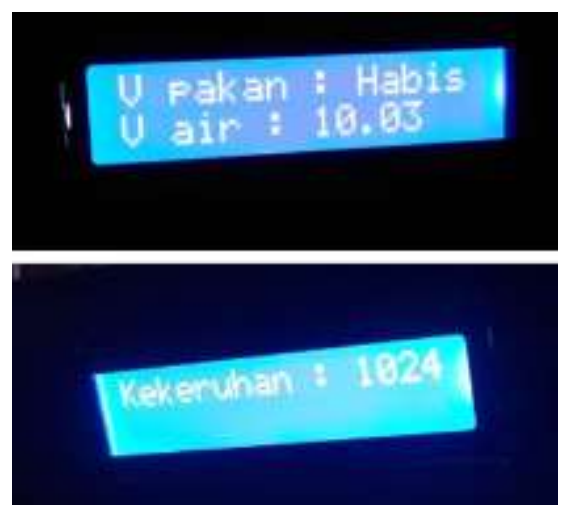

Figure 9. LCD Screen

The smart aquarium is developed by using the Internet of Things to enable users to do the aquarium condition monitoring even from the distance through the website page. In the smart aquarium system, the website page functions to give information about the water height level, fish food volume, and water turbidity level as it is shown in Figure 10. The feeding schedule can also be arranged through the website.

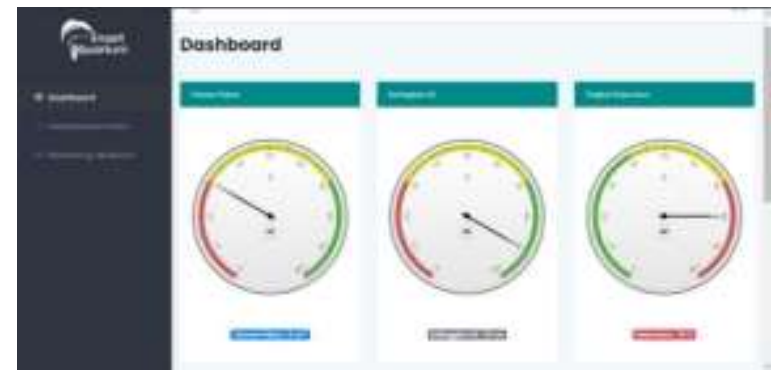

Figure 10. Aquarium status page.

Not only the aquarium status which can be monitored through the website page but also the activities in the aquarium is recorded on the website. The system can only save the data of aquarium activities in the last three days. The data which are noted on the website are about the feeding time and status, the water disposal, the water replacement, and the water height level. The monitoring history page can be seen in Figure 11.

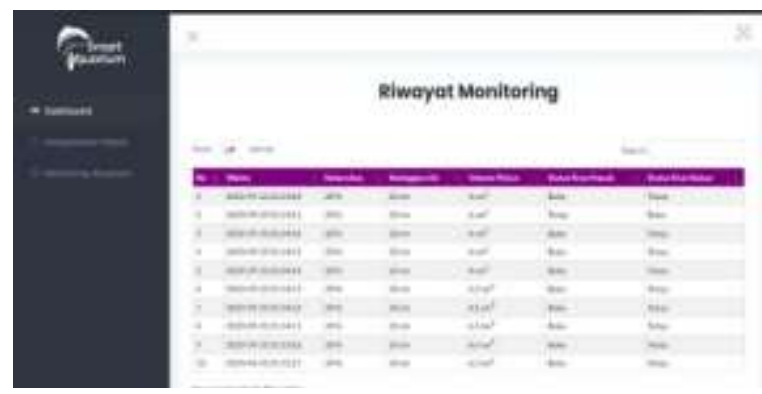

Figure 11. Monitoring history page

\section{CONCLUSION}

This aquarium is using a NodeMCU ESP8266 as a microcontroller and can feed the fish automatically based on the feeding schedule. This aquarium also can do water replacement automatically if the water has turned turbid due to detection by an LDR sensor.

By using the automatic aquarium, the owners do not need to manually feed the fish and clean the aquarium as often as possible. The use of a website page in the automatic aquarium enables the owners to monitor the aquarium condition from the distance. The owners can also feed the fish and set the feeding schedule through the website page.

\section{REFERENCES}

[1] KBBI, "Definisi Akuarium, Kamus Besar Bahasa Indonesia," 2019. www.kbbi.co.id.

[2] BPS, "Badan Pusat Statistik," 2017. bps.go.id.

[3] A. Jumaidi, H. Yulianto, and E. Efendi, "Pengaruh Debit Air terhadap Perbaikan Kualitas Air pada Sistem Resirkulasi dan Hubungannya dengan Sintasan dan Pertumbuhan Benih Ikan Gurame (Oshpronemus Gouramy)," e-Jurnal Rekayasa dan Teknol. Budid. Perair., vol. 5, no. 2, pp. 587-596, 2017.

[4] R. Saputra and M. Syafrullah, "Aplikasi Pemberi Pakan Ikan Otomatis Menggunakan Mikrokontroler ESP8266 Berbasis 
Web ( Studi Kasus : Gedung Graha Mitra )," SKANIKA, vol. 1, no. 2, pp. 718-724, 2018.

[5] N. I. Widiastuti and R. Susanto, "Kajian sistem monitoring dokumen akreditasi teknik informatika unikom," Maj. Ilm. UNIKOM, vol. 12, no. 2, pp. 195-202, 2014, doi: 10.34010/miu.v12i2.28.

[6] A. Marzali, "Menulis Kajian Literatur," ETNOSIA J. Etnogr. Indones., vol. 1, no. 2, pp. 27-36, 2016, doi: 10.31947/etnosia.v1i2.1613.

[7] W. Danto, A. P. Pertiwi, and K. A. Laksitowening, "Analisis Kebutuhan Fungsional Sistem Informasi IT Telkom Menggunakan Balanced Scorecard," Konf. Nas. Sist. Inf., no. Februari, 2011. 